\title{
Research Paper: A Survey on Integral Futures Studies Capacity to Overcome the Challenge of Meeting Future Water Resources for Food Production at the National Level in Iran
}

\author{
Ali Akbar Azimi Dezfuli" ${ }^{*}$ Roknoddin Eftekhari Abdoreza², Ghadir Nezamipur ${ }^{3}$, Eva Hideg $^{4}$
}

1. PhD Candidate, Institute of Futures Studies, Imam Khomeini International University, Ghazvin, Iran

2. Professor, Department of Geography and Rural Planning, Faculty of Humanities, Tarbiat Modares University, Tehran, Iran.

3. Assistant Professor, Department of Strategic Management, Science and Research Branch, Islamic Azad University, Tehran, Iran.

4. Professor, Department of Economic Geography and Futures Studies, Faculty of Social Sciences and International Relation, Corvinus University of Budapest, Budapest, Hungary.

\begin{tabular}{|c|c|}
\hline $\begin{array}{l}\text { Use your device to scan } \\
\text { and read the article online }\end{array}$ & ditation: Azimi Dezfuli, A. A., Eftekhari Abdoreza, R., Nezamipur, Gh., \& Hideg, E. (2017). A Survey on Integral Futures \\
\hline 口riptra & $\begin{array}{l}\text { Studies Capacity to Overcome the Challenge of Meeting Future Water Resources for Food Production at the National Level in } \\
\text { Iran. Journal of Sustainable Rural Development, 1(1), 53-68. https://doi.org/10.18869/nrip.jsrd.1.1.51 }\end{array}$ \\
\hline 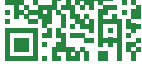 & doi : https://doi.org/10.18869/nrip.jsrd.1.1.51 \\
\hline
\end{tabular}

Article info:

Received: 14 Dec. 2016

Accepted: 03 Feb. 2017

\section{Keywords:}

Integral futures studies, Foresight, Water crisis, Food security, Virtual workshop

\section{ABSTRACT}

Purpose: Coping water scarcity and food production in Iran require some appropriate Futures Studies (FS) paradigm. Integral Futures Studies (IFS) is applied and examined for studying the futures of water supply for food production in I. R. of Iran.

Methods: Virtual workshop, as a web based foresight procedure, is developed and implemented according to IFS circumstances for a future based structured social dialogue, among Iranian stakeholders. The first phase of the foresight procedure (pre-foresight) lasted 6 months, 105 national stakeholders were registered to take part in online discussions, surveys, and workshops, and to share their ideas and opinions on future agendas and trends. During this phase, the objective and subjective parts of the knowledge on shaping the future were integrated into one system. Finally 36 volunteers evaluated the pre-foresight.

Results: IWRM and AM are some global approaches to solve the water allocation challenges at watershed or national levels. Under such circumstances future studies needs to bring closer divergent views, promote understandings, and interests; strengthen their consensus on the future interests and benefits of the nation, and renew their commitment to the preservation and management of water resources. So IFS could regard as a more suitable paradigm through coping water challenges for food production at national level. Behind some special results, procedure results $(5 \mathrm{C})$ of this study were examined. The percentages of participants consensus on the effectiveness of the examined issues were as follows: 1) Promoting thinking about the future (91\%); 2) Clarifying the effective factors (88\%); 3) Promoting thinking systematically (91\%); 4) Forming new networks and communications (78\%); 5) Promoting social learning about the subject of the study $(89 \%)$; 6) Promoting cooperation among the participants (72\%); and 7) Promoting consensus among the relevant stakeholders (75\%).

Conclusion: Finally, virtual workshop as a web based procedure and according to IFS circumstances, could promote a deep and continual structured and future oriented dialogue among the relevant stakeholders across the country for coping water challenges for food production at national level.

\section{* Corresponding Author:}




\section{Introduction}

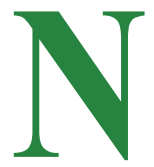

otwithstanding other water consumptions, a human being drink, on average, 2 to 4 liters of water daily, while he consumes 2000 to 5000 liters of virtual water (United Nation, 2014). By definition, virtual water is the water embedded in a product; i.e. the amount of water consumed to produce that product (Renault, 2003). As depicted in Figure 1, agricultural water consumption in Iran and neighboring countries is greater than urban and industrial water consumptions. Of course, the proportions of municipal, industrial, and agricultural water withdrawals vary from country to country, due to different climatic conditions, Gross Domestic Product (GDP) growth, quality of water supply infrastructures, water allocation, water consumption, and other socioeconomic factors. Along with climatic changes, population growth, and increase in demand for biofuel by 2025, the global demand for corps is expected to increase by $46 \%$ (65\% in the developing countries); but the existing water resources will limit the further expansion of irrigated agriculture. Under such conditions, the farmers should produce more food for millions of people who will be added to the world population; while, there will be almost no new economical water resources available to the farmers (Hanjra \& Qureshi, 2010).

According to the International Water Management Institute, in 1950, twelve countries with a total population of 20 million faced water shortage; while, in 1990, this number increased to 26 countries with a total population of 300 million. It is predicted that 65 countries with a total population of over 7 billion will face water shortage by 2050. Moreover, around 1960, most countries were selfsufficient in food production; however, by 2025, a majority of these countries will not be major crop producers. Among the 183 countries of the world, only USA and Canada are now the main crop exporters; however, because of the population growth in USA, its crop export capacity is expected to diminish in the next 25 years. In other words, the surplus of food products that could be supplied to the world markets shrink, while the global food demand rises; therefore, the supply of basic foodstuff in the world diminishes (Ehsani \& Khaledi, 2003; Hanjra \& Qureshi, 2010).

Futures of water supply for sufficient food production

Iran is situated in a region with a moderate to desert type climate; and only a small part of it receives adequate rainfall for dry farming. The amount of renewable water per capita in Iran decreased from $5500 \mathrm{~m}^{3} /$ person in 1961 to $2100 \mathrm{~m}^{3} /$ person in 1997, and to $1769 \mathrm{~m}^{3} /$ person in 2013 (Kesha- varz \& Sadeghzadeh, 2000; Steduto, Faurès, Hoogeveen, Winpenny, \& Burke, 2012). The shrinkage of underground water resources in Iran, similar to other countries of the world, is caused by social and technological factors rather than natural conditions (Haddeland et al., 2013). The consequences are the drying of Zayandeh-Rud River, Hamun and Urmia lakes, and the receding of underground water levels in some regions such as Birjand (Javan \& FalSoleyman, 2008) and Jiroft watersheds (Paydar Golsang, 2013). According to Table 1, as the share of agricultural water use in accordance with domestic food demand increased (Agricultural Engineering Research Institute, 2015), some stakeholders and social groups started to emphasize on the import of virtual water (Zareie \& Jafari, 2011; Mircholi, Faramarzi, \& Soltani, 2013; Nozari \& Kiumarsi, 2015).

However, other stakeholders based on social, economic, and political measures emphasized on self-sufficiency in food production and did not believe that the import of virtual water was a safe and reliable option (Khadem Adam, 2000; Gharib, 2011; Esmaeelifar, 2013; Brown, 2013). As shown in Figure 2, self-sufficiency has encountered high uncertainties during the last 2 decades, $1^{\text {st }}$ due to drought in 2008, as natural uncertainties and 2nd due to governmental policies adopted in 2013, as social uncertainties (Agricultural Planning Economic and Rural Development Research Institute, 2016).

\section{Research question}

The research question of the present study is which futures research methodology is more suitable for studding the futures of water supply for food security at national level?

\section{Literature Review}

The Food and Agriculture Organization (Steduto et al, 2012) proposed some principles to achieve food security in countries which face water scarcity. These principles that emphasized on a comprehensive program to balance water supply and demand for food productions at national level included 1) Providing the solutions based on a clear understanding of the factors and effects of water crisis, 2) Making policies on a holistic and systemic viewpoint of financial decisions about costs and benefits instead of financial costs, and the potential social capacities including the participation and training of stakeholders should be considered, 3) Considering proper degrees of water governance and institutional capacity at national levels, 4) Acting and adapting response to local conditions according to the environmental, social, and economic conditions of a country, 5) Balancing the 


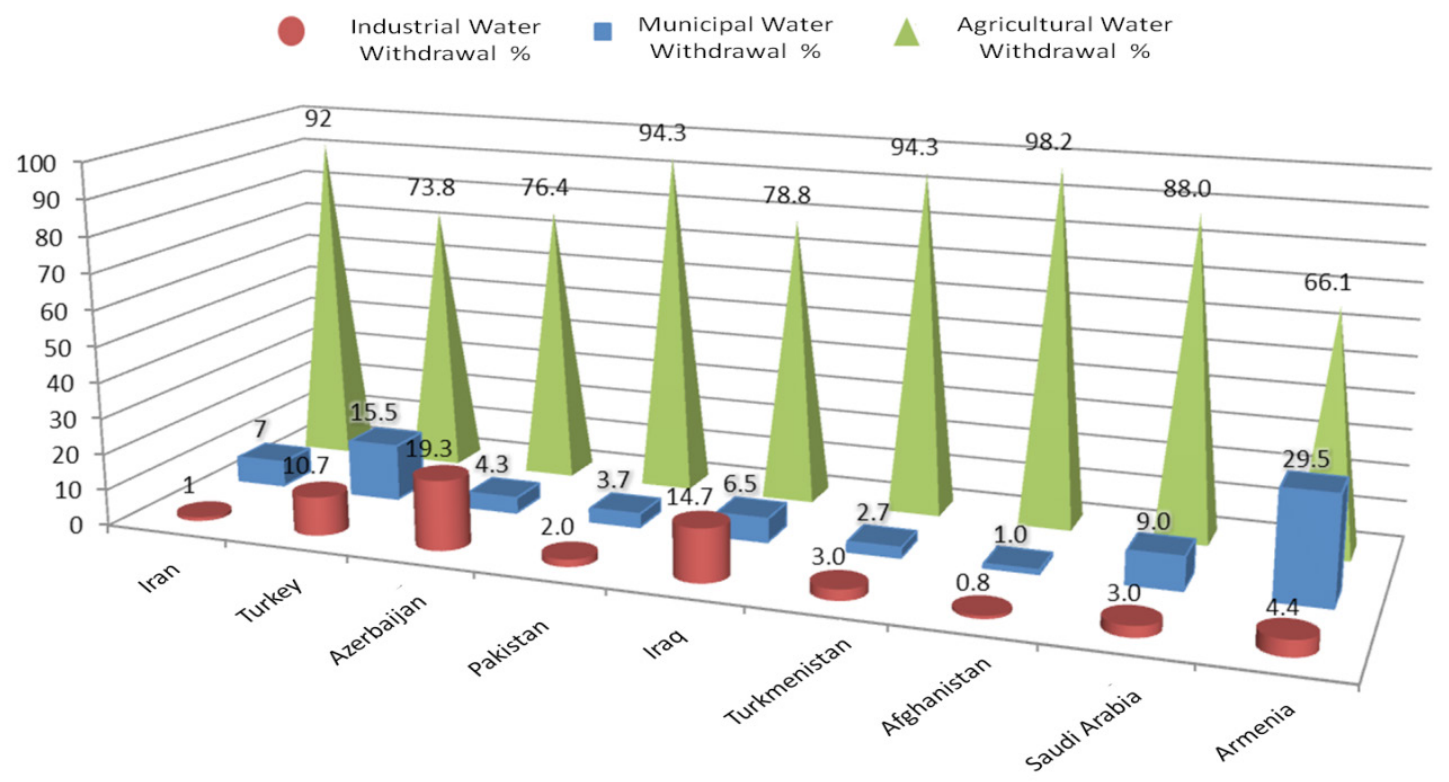

JSRD

Figure 1. Comparing the shares of municipal, industrial, and agricultural water withdrawals between Iran and the neighboring countries (FAO, 2014)

policies related to water and food securities; trying to converge the effective policies in the agricultural water supply and demand chain, including the policies on the pricing of goods and services, 6) Anticipating change through robust decision-making and adaptive management; ensuring robust decision-making and applying the contingency management plans (Steduto et al, 2012).

Since managing water resources for food production needs to gain some information about the future, review on recent water resource management approaches and FS paradigms could help to recognize suitable FS approach.

World implementation framework for coping with water scarcity and food production

\section{IWRM}

The IWRM is a systematic process for the sustainable development, allocation, and monitoring of water-resource used in the context of social, economic and environmental objectives. IWRM is employed to recognize the different and competing groups involved, the sections that use or misuse water, and also the environmental needs. Management of water resources is coordinated across various sectors (agriculture, industries, and urban) and social groups at watershed level through the integrated system of IWRM. This process is supported by some tools such as social and environmental assessments, economic instruments, and information and monitoring systems.

\section{Water governance}

Water governance is another approach to water management with 3 mutually reinforcing and complementary dimensions: 1) Effectiveness; which is related to the governance contribution clearly defines the goals of sustainable water policy and aims at all levels of government to execute the policy goals, and accomplish the expected targets, 2) Efficiency; which is related to the governance

Table 1. Trends of iran's agricultural production and the corresponding water use from 2003 to 2012

\begin{tabular}{ccccccccccc}
\hline Year & $\mathbf{2 0 0 3}$ & $\mathbf{2 0 0 4}$ & $\mathbf{2 0 0 5}$ & $\mathbf{2 0 0 6}$ & $\mathbf{2 0 0 7}$ & $\mathbf{2 0 0 8}$ & $\mathbf{2 0 0 9}$ & $\mathbf{2 0 1 0}$ & $\mathbf{2 0 1 1}$ & $\mathbf{2 0 1 2}$ \\
\hline $\begin{array}{c}\text { Total agricultural product } \\
\text { (Mton) }\end{array}$ & 68.7 & 76.1 & 73.6 & 80.1 & 64.3 & 71.6 & 82.9 & 86.6 & 90.0 & 94.0 \\
$\begin{array}{c}\text { Water consumption } \\
\left(\mathrm{mm}^{3}\right)\end{array}$ & 73300 & 78500 & 72100 & 79500 & 63500 & 70700 & 74200 & 67300 & 75300 & 78900 \\
\hline
\end{tabular}




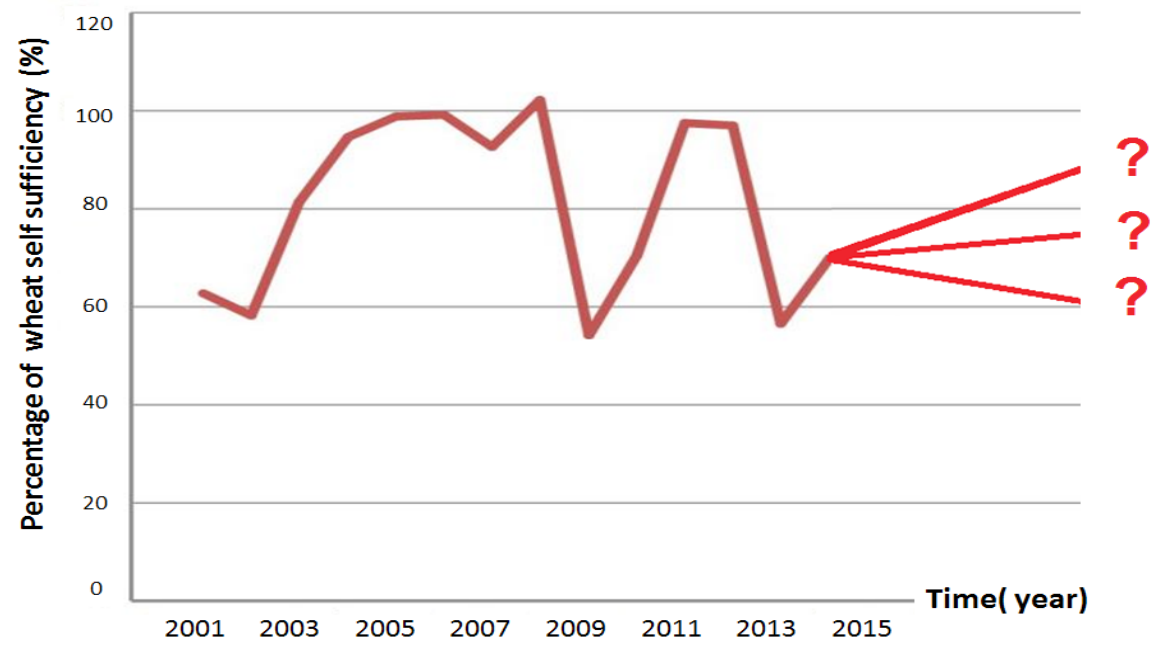

JSRD

Figure 2. Percentage of wheat production self-sufficiency from 2001 to 2025 in Iran (Agricultural Planning Economic and Rural Development Research Institute, 2016)

contribution to extend the benefits of sustainable water management and welfare in the society at the lowest cost, and 3) Trust and Engagement; which are related to the governance contribution to gain public confidence and ensure the inclusion of stakeholders through democratic legitimacy (Hassing, Ipsen, Jinch, Larsen, \& Lindgaard, 2006; Global Water Partnership, 2009; Organisation for Economic Co-operation and Development, 2015).

Recently, some theoretical discussions and practical efforts are made to implement IWRM in Iran (Zargarpur \& Nourzad, 2009; Nikuee \& Zibaee, 2012). Zargarpur (2009) introduced the IWRM as a global approach to deal with the challenge of water shortage. His model includes the following key issues or indices: 1) Integration of water resources and environmental management, 2) A systemic outlook on water shortage challenges, 3) Complete participation of stakeholders, 4) Consideration of social aspects, 5) Improvement of human resources, 6) Availability of basic information, 7) Fair allocation of water resources, 8) Priority and dominant role of water in adopted [country-specific] policies, 9) Accepting the watershed region as the most important unit, 10) Integration of water and soil management, 11) Integration of surface and subsurface water resources management, 12) Implementation of coordinated policies in the water sector, 13) Supplying safe and healthy water for people (Zargarpur \& Nourzad, 2009; Nikuee \& Zibaee, 2012; Safavi \& Shisheforoosh, 2013).

The "IWRM Zayandeh-Rud River project" was implemented during 2010-2015. The project aimed at developing sustainable water resources for the stakeholders of Zayandeh-Rud watershed (Figure 3) including the decisionmakers and the affected people who face severe challenges due to the rapidly declining amount and quality of available water. Therefore, the relevant skills and capacities of Iran and Germany were put together to develop sustainable water management along the river and balance the competing agricultural, industrial, municipal, and environmental water demands (Mohajeri et al., 2016).

However, IWRM is required to manage and balance water resources with different water demands at watershed scale; to supply water for agricultural production at national level it is necessary to balance water resources with different water demands at national level.

\section{Adaptive management}

Adaptive management can be defined as a systematic process to improve management policies and practices

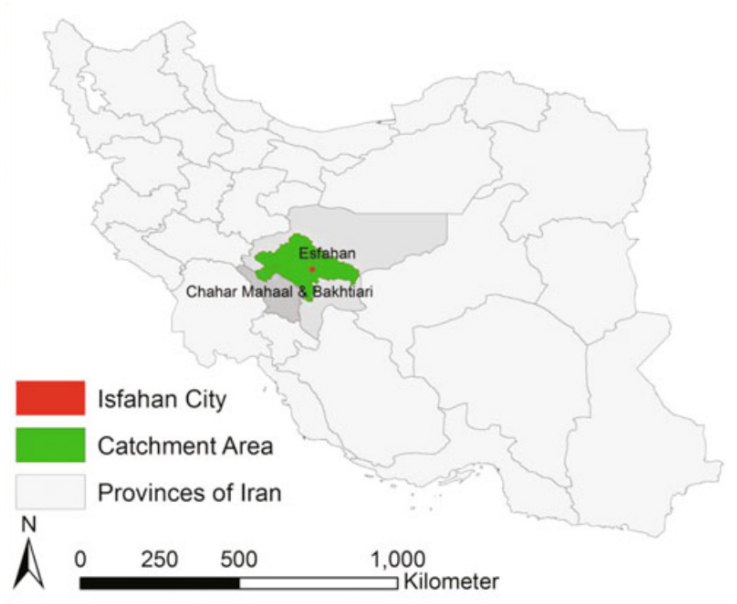

(JSRD

Figure 3. Map of the Zayandeh-Rud Basin in Isfahan, Iran (Mohajeri et al., 2016) 
by considering the outcomes of the implemented management strategies. Adaptive management recognizes the high level of uncertainty associated with future situations, and emphasizes on flexible planning that allows regular upgrading of plans and activities. The responsiveness is only possible in case of updating the information and knowledge, continually monitoring the information management systems, and providing decision-makers with reliable information. External factors such as climate change, global, financial, and economic shocks, and change of international cooperation agreements may derail coping strategies. Scenario building, which is an integral part of strategy development, is a pivotal method to identify and maintain risks, and the developing robust responses to uncertainty of future situations (Pahl-Wostl, et al., 2007; Huitema et al., 2009; Steduto et al, 2012; Allen, Fontaine, Pope, \& Garmestani,, 2011).

\section{In addition}

IWRM requires balancing all water resources and water demands sectors by contributing main related stakeholders at the watershed scale. Water governance emphasizes on improving the relations among main stakeholder from farm to national scale. AM focuses to improve reflective cycles in water management process and recognizes the high level of uncertainty for exploring alternative futures. It explores the future via natural and controllable uncertainty. In such situations, more than one uncontrollable uncertainties exist.

Now it is tried to find an appropriate methodology to study the futures of water supply for food production at national level. Indeed, to study the subject, it is necessary to consider of the following issues: A) Paying simultaneous and integrated attention to the dwindling levels of water resources at watersheds and enough food production at the national level, B) Considering natural and social factors such as integrated and interrelated systems that affect the supply of water for the food production at national level (Figure 4), C) Various groups such as farmers, experts, non-governmental organizations (NGOs), policy-makers in agricultural and water administrative departments have different values, benefits, and future interests; therefore, by the participation of different and scattered stakeholders from farm to watershed at national level in adopting policies about water resources management ${ }^{1}$, they accept their role in the implementation of such policies, D) The need to reduce the existence of high levels of uncertainties both in natural and social factors (Figure 2), and E) Need to

1. This approach could be named Integrated Water Resources Management for Food Production (IWRMFP). implement an iterative, structured, and goal-oriented learning by doing processes to build knowledge and improve management over time.

\section{Futures studies paradigms}

Futures studies is emerging as a new social scientific knowledge, and the community of futurists is trying to find which concept, methodology, procedure, and results are more acceptable in their research activities (Van Vught, 1987; Aligica, 2003; Bell, 2011; Mettler, 2005; Morgan, 2011; Hideg, 2013). Hideg (2013) tried to introduce a framework for methodological features of futures studies according to the main scientific paradigms. She specially discussed 3 challenges confronted by social sciences. These issues were: sustainability, democratic participation, and creating new knowledge. She evaluated the development track of futures studies and its paradigms according to the meta-analysis, and discussed their capacities to respond to the new societal demands.

Dealing with sustainability emphasizes the analysis between environmental and human dynamic interactions and their foreseeing and planning. Democratic participation is increasingly important to solve societal problems and disagreements. Democratic participation provides a new framework for individuals, in which they are able to affect their own living environment and societal position. According to recent paradigms of social sciences, new knowledge is created not only by the social elite, but also by all the individuals in a society.

Additionally, new knowledge has to be organized and created via participation in interactivities. The creation of new knowledge is a continuous action, and a part of the reflective societal learning process. Thus, the key issue in the societal evolution is the development of individual and social knowledge bases with very strong interconnections (Hideg, 2013). Therefore, integral futures studies (IFS) seems to be able to prepare wide, yet acceptable, postulates to study complex problems and subjects such as the futures of water supply for food production.

\section{Foresight}

It seems that a close definition for foresight in the context of IFS paradigm would be as such: foresight is a systematic, participatory, future-intelligence-gathering, and medium-tolong-term vision-building process aimed at enabling present-day decisions and mobilizing joint actions. Foresight is a process for addressing this strategic question: how to survive in an increasingly competitive environment (Voros, 2003). 


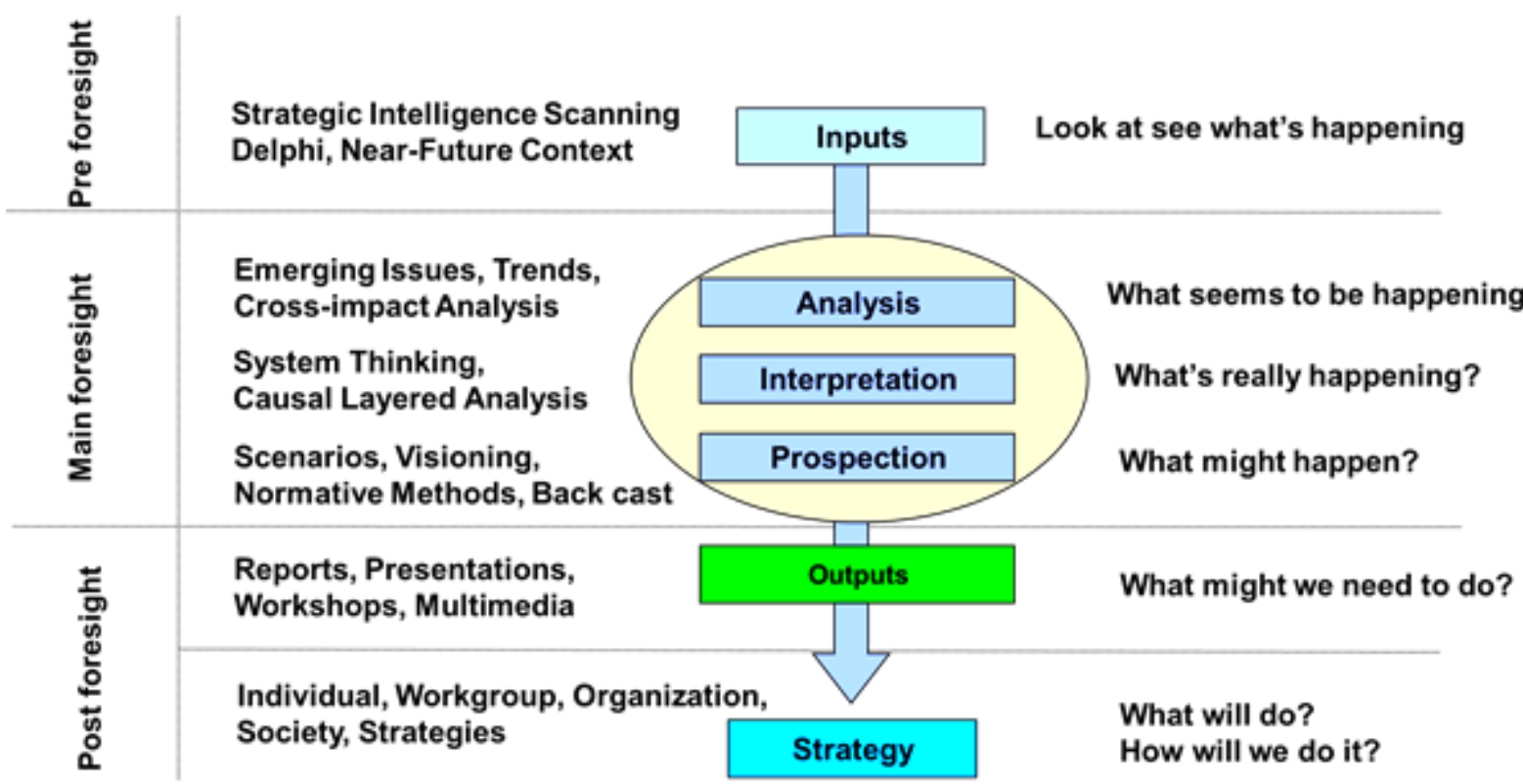

JSRD

Figure 4. Generic structure of foresight process, order of proposed questions and the methods could applied in the foresight, adopted from (Voros, 2003: 12-15)

In this process, key actors and stakeholders, by direct participation in workshops, discuss their viewpoints, and exchange their ideas and opinions and other means (Gavigan et al., 2001). The goals of foresight might be divided into 2 main categories: 1) Specific goals; eg, scenarios to supply water for food production till 2025; and 2) General goals or 5Cs, which represents the promotion of communication, concentration on longerterm futures, coordination, consensus and commitment among stakeholders (Georghiou, 2003; United Nations Industrial Development Organization, 2005).

\section{Pre-foresight}

In this phase, information is gathered and environment scanned to achieve strategic intelligence. Many methods and techniques such as Delphi and environmental scanning could be applied in this phase.

\section{Main-foresight}

This phase includes 3 broad steps with a logical sequence: 1) Analysis, which is best considered as a preliminary stage to more in-depth work, rather than as a standalone technique by itself, 2) Interpretation, which seeks to explore beneath the surface of the analysis to look for deeper structure and insights; this is the realm of critical futures studies, and 3) Prospection, purpose- fully looks toward creating views; in this step, different views of alternative futures are clearly examined or created, and scenarios, perspectives, and normative methods are located in the broader foresight process.

\section{Post-foresight}

The outputs of foresight work are tangible and intangible; tangible outputs include the actual range of options generated by the work and intangible outputs refer to the changes in thinking engendered by the whole process, especially the insights developed in the interpretation step, and by the creation of forward views in the prospection step. The intangible output is difficult for some hardheaded, "inconvincible" people to appreciate, or even recognize. But it is undoubtedly the more important form of output it alters mechanisms of strategy development, namely the perceptions involved in strategizing (Gavigan et al, 2001; Voros, 2003; Georghiou, 2003; United Nations Industrial Development Organization, 2005).

Some lessons from current national agricultural foresight

Azimi (2008) reviewed some national foresights with emphasis on agricultural sector in some countries such as China (Teruhisa \& Yoshika, 2006), England (Georghiou, 1996), and Czech Republic. In this review 
Table 2. Comparing Characteristics of the Adopted Future Studies Paradigms

\begin{tabular}{|c|c|c|c|}
\hline $\begin{array}{l}\text { Paradigms } \\
\text { Components }\end{array}$ & $\begin{array}{c}\text { Positivistic Futures } \\
\text { Studies }\end{array}$ & Critical Futures Studies & $\begin{array}{l}\text { Integral Futures Studies/ } \\
\text { Practical Approach }\end{array}$ \\
\hline $\begin{array}{l}\text { Comprehension of the } \\
\text { future and the world } \\
\text { futures studies }\end{array}$ & $\begin{array}{l}\text { It will physically occur } \\
\text { later; it is genetically } \\
\text { connected to the present } \\
\text { and past; it can be ob- } \\
\text { served by an observer }\end{array}$ & $\begin{array}{l}\text { It is a part of the human world } \\
\text { which currently exists in the } \\
\text { thoughts, emotions, and beliefs of } \\
\text { people, and it is constantly shaped } \\
\text { in their communications }\end{array}$ & $\begin{array}{c}\text { Future is a process of mental construc- } \\
\text { tions and reconstructions born in a } \\
\text { certain space and time of the human } \\
\text { world }\end{array}$ \\
\hline Futurists role & Observer & Participant-observant & Participant-observant \\
\hline $\begin{array}{l}\text { The field of inquiry in } \\
\text { futures studies }\end{array}$ & $\begin{array}{l}\text { The future of society and } \\
\text { issues concerning the } \\
\text { future of human beings, } \\
\text { complexity } \\
\text { and, dynamics }\end{array}$ & $\begin{array}{l}\text { People's and their groups' relation } \\
\text { to the future, formation of ideas, } \\
\text { and relations about the future of } \\
\text { communities }\end{array}$ & $\begin{array}{l}\text { Find different actors and knowledge, } \\
\text { among others the representatives of } \\
\text { non-human systems and scientific } \\
\text { knowledge, interconnect them in space } \\
\text { and time regarding the future construc- } \\
\text { tional tasks }\end{array}$ \\
\hline $\begin{array}{l}\text { The objective and task } \\
\text { of futures studies }\end{array}$ & $\begin{array}{l}\text { Prediction of the range of } \\
\text { probable future events }\end{array}$ & $\begin{array}{l}\text { Participation in the social transfor- } \\
\text { mational cycle; support of forming } \\
\text { future thinking at community level }\end{array}$ & $\begin{array}{c}\text { Creation of future knowledge about } \\
\text { the mutual survival of human and non- } \\
\text { human worlds }\end{array}$ \\
\hline $\begin{array}{l}\text { Methodological } \\
\text { principals } \\
\text { Futures studies }\end{array}$ & $\begin{array}{l}\text { Complex problem treat- } \\
\text { ment, dynamic modelling }\end{array}$ & $\begin{array}{l}\text { Communicative simulation of critic } \\
\text { and transformational cycle, placed } \\
\text { in context }\end{array}$ & $\begin{array}{c}\text { futures constructions would shaped } \\
\text { based on the participation of differ- } \\
\text { ent actors into a creative and dynamic } \\
\text { learning process }\end{array}$ \\
\hline $\begin{array}{l}\text { Rules for method } \\
\text { application in futures } \\
\text { studies }\end{array}$ & $\begin{array}{l}\text { Various objective } \\
\text { methods }\end{array}$ & $\begin{array}{l}\text { Combining the subjective and } \\
\text { mental methods at personal and } \\
\text { group levels. } \\
\text { Participation of stakeholders is } \\
\text { needed. }\end{array}$ & $\begin{array}{l}\text { Subjective, individual, group- and } \\
\text { internet-based methods to connect } \\
\text { different knowledge and create new } \\
\text { knowledge of the future, and the use } \\
\text { of quantitative methods subservient } \\
\text { to the participatory creation of new } \\
\text { knowledge }\end{array}$ \\
\hline $\begin{array}{l}\text { Worthwhileness and } \\
\text { utility of futures stud- } \\
\text { ies results }\end{array}$ & $\begin{array}{l}\text { Verification, reliability, } \\
\text { and fulfilment }\end{array}$ & $\begin{array}{l}\text { Becoming subject of social dis- } \\
\text { course; transparency, controllabil- } \\
\text { ity, and repeatability; acceptance } \\
\text { at community level; reflection on } \\
\text { the reflected }\end{array}$ & $\begin{array}{c}\text { Partial falsification, transparency, } \\
\text { comprehensibility, and acceptability } \\
\text { used in other human actions; possibility } \\
\text { to improve, utilize, and explore for } \\
\text { theoretical futures }\end{array}$ \\
\hline
\end{tabular}

they reported on topics such as foresights workflow, work organization, scope, methods, budgets and timetables, restrictions, the general results, and the specific results (eg, science and technology priorities). Furthermore, some of the above-mentioned countries, especially emphasised on general results. In almost all these reports, the obtained results were not discussed from the perspective of scientific acceptability as the field of futures studies. The major findings of these experiences are introduced as follows:

1) Governmental support, but no direct interference: Governmental support at high levels is necessary for the activities related to foresight and to provide a base for the participation of public sector in the foresight process and its management. However, governments should not directly interfere in foresight implementa- tion and in the formation of its results; because some administrations might dictate their own unilateral interests, 2) Formation of a stakeholders' cooperation network is a key factor in the success of the foresight process; due to direct effect of every participants in the formation of the future knowledge, 3) Bottom-up or top-down procedure: Foresight is not necessarily a bottom-up process, and it might incorporate the ideas of various stakeholders, and the recommendations of the upstream national and formal documents, governmental organizations, etc., 4) First round is necessary but not sufficient: In the $1^{\text {st }}$ round of the foresight procedure, it is not expected to obtain accurate or proper results regarding the specific goals; therefore, it is necessary to modify and repeat the foresight process and complete it in subsequent steps, 5) Foresight promotes futures thinking in the society, 6) Reducing the gaps 
between research and development units: Foresight reduces the gaps among research units, policy-making and operational programs, and 7) Importance of general results: Countries often focus on the process results (5Cs), rather than special results (Azimi, 2008).

Attributes of foresight under Integral Futures Studies (IFS) in water crisis and food production field

Now, the usefulness of IFS paradigm in the context of national water crisis and food production is discussed. In Table 2, IFS with a practical approach is regarded as an evolution of futures studies. In an integral framework, it is possible to use the capacity of previous paradigms to help the current communities deal with new challenges such as sustainability and public participation to create the new knowledge. In this approach, the social and natural systems are considered.

Comprehending the future and the world: The futures of water supply for food production are affected by natural factors, such as climatic conditions and the quantities of surface and subsurface water resources, and also by the stakeholders' perceived knowledge or common sense about the shortage of natural resources and their benefits and interests gained by managing water supplies for food production. Therefore, agricultural water demand futures are affected by the trends of climate, rainfall, soil and water resource, and also by the main stakeholders' viewpoints and actions.

Research field: Farmers, policy-makers, researchers, and NGOs active in agricultural and environmental fields at national level (stakeholders) influence both the natural and social systems (Figure 4). Such areas cannot be investigated solely by a positivistic or critical approach. In the critical methodology, the only important issues are the people and their views and opinions about the future of communities. While in this research, natural resources and conditions are one of the key elements that affect a social system and they themselves are affected by people and the social systems.

Futurists' role: In the positivistic paradigm, a futurist should try to predict the futures of climate, participation and water resources, and study them objectively. However, to guide his/her research in the right direction, the futurist needs to look at social facts and factors from the perspective of stakeholders. Futurists should have an understanding of various social structures and realize the stakeholders' values and interests and consider them in the research process. In this approach, futurists are not divorced from the phenomena being studied and have a reflexive role. Futurists with this worldview believe that understanding and applying the stakeholders' experiences are as important as focusing on the explanation, prediction, and control of the studied issue. They should also consider their own standpoint about the subject. In this approach, the futurist is the main research tool.

The goal and mission of this research: The current study aimed at creating the future knowledge about human and non-human worlds. It is achieved by getting various stakeholders who are involved in shaping the future to participate in a process of communication and dialogue at different community levels.

Methodological principles of IFS and the research context: The methodological principles in this approach refer to the features of future constructions that emerge from the participation of different stakeholders in a creative and dynamic process in which they learn from each other and share their knowledge on natural resources. In this approach, the discussed methodology is not completely precise, because human beings do not always act logically or predictably; while, the structure and order of methods are important. However, although the social world is not orderly or systematic, it is important that the researcher proceeds in a well-structured and systematic way.

Rules for method application in IFS: Some methods used in practical futures studies to combine different knowledge together and create new knowledge about the future are either subjective, individual, groupbased, or internet-based approaches. These methods provide insights from the perspective of stakeholders for the futurists, enabling them to see things as their informants (including the stakeholders) do. In IFS the use of objective and quantitative methods are in the service of the participatory creation of new knowledge.

Worthiness of IFS results: The worthiness of IFS results which comprise the special results (scenarios) and general results (5Cs) are judged by means of partial falsification. These results could be evaluated with regards to their acceptability, transparency, comprehensibility, and their applicability to other human activities. They could also be evaluated with the goal of improving and using them in the investigation of theoretical futures.

Comparing usefulness of water supply and food production foresight under integral futures studies with other paradigms

The parameter of water supply for food production at national level is influenced by natural systems; therefore, 
it requires quantitative analysis and prediction. However, as this parameter is also affected by the values, opinions, and actions of various dispersed stakeholders across the country, these beneficiaries should address, in their communications and dialogues, the disparities between their interests, actions, common senses, understandings of relevant factors and drivers, and their underlying frameworks, recognize the uncertainties, adapt their outlooks, and reach a final consensus about the futures of water supply for food production. Hence, futures studies on water supply for food production, under the integral approach, should use a network-based method to facilitate communication and interaction among the relevant stakeholders and provide a process for comprehensive and continual dialogue and learning by doing, as part of the adaptive management process.

\section{Methodology}

Virtual workshop as an integrated futures studies method

Following the introduction of IFS paradigm, research works mainly emphasized the roles and responsibilities of humans in shaping the future and also the roles played by natural systems. Hideg (2013) implemented a web-based method to implement foresight under IFS. She used the internet to extend the interactions of various stakeholders and established interactivity and social dialogue to improve social learning and social innovation (Hideg, Novaky, \& Alács, 2014). The social dialogue introduced in her work had multiple objectives: 1) A wide participation of stakeholders naturally allowed them to take part in the decision-making process, 2) The formation of a consensus on the developed foresight was an instrumental contribution to the project, and 3) Learning from other participants was a key aspect of the social dialogue. She described the future of a Hungarian vocational training project to fully explore the opinions, imaginations, and expectations of various stakeholders (Hideg, Novaky, \& Alács, 2014).

Implementation of virtual workshop for IWRMFP in Iran

By using the foresight procedures in the framework of an interactive website, a virtual workshop was designed under IFS methodology for IWRMFP in Iran. Virtual workshop allows various national stakeholders to participate in the foresight. Through this method, stakeholders were organized in three groups: water supply group, agricultural water consumption group, and wheat consumption group. The futurist and the participants in the program could interact together through the developed web page ${ }^{2}$. Figure 5 illustrates this virtual workshop, which includes the pre-foresight, main-foresight, and post-foresight phases. In this paper, the pre-foresight phase is introduced and evaluated.

During the pre-foresight phase that took 6 months, 105 native participants, as representatives of farmers, agricultural and water supply NGOs, researchers, governors, and policy-makers, registered in the virtual workshop; and special user names such as farmer 1 , farmer $2, \ldots$, water-govern 1, water-govern 2, ..., agri-ngo1, agringo $2, \ldots$, etc., were assigned to them according to their professions and fields of expertise. Then, each participant could start anonymous dialogues with others, and change his/her opinions during the study. Therefore, the anonymity postulate of Delphi was applied. Also, this method can be regarded as a web-based Delphi method.

During this phase., research efforts, and social dialogues and discussions were around the following issues: 1) The importance of the problem, 2) Recognizing the set of factors that affect the subject and also recognizing more important factors and players in the area of water supply and wheat production, 3) Scientific papers (Figure 6) and controversial news hot news, uploaded onto the web-page by research participants. 4) The researcher-made 34 structured interviews were conducted among the stakeholders and the results were uploaded onto the web-page. This procedure helped the stakeholders participate in structured dialogues, and could easily revise their viewpoints about the challenges.

During this phase, the futurist acted as a consultant and by presenting his judgment and viewpoints to the others and considering the problem from the standpoint of participants, encouraged them to discuss their interests and ideas. Then, the participants encouraged to put their ideas and opinions about the main problem and expressed their viewpoints regarding the future values and interests. In parallel, statistical data about wheat cultivation areas, wheat production, water resources, wheat consumption, water demand of wheat, etc. uploaded onto the web-page and used for descriptive and trend analysis. In this capacity, a virtual workshop could be regarded as an environmental scanning tool (Slaughter, 1999).

According to Figure 5 during this pre-foresight phase, 105 native participants, as representatives of farmers, agricultural and water supply NGOs, researchers, gover-

2. wWw.msfs.ir 


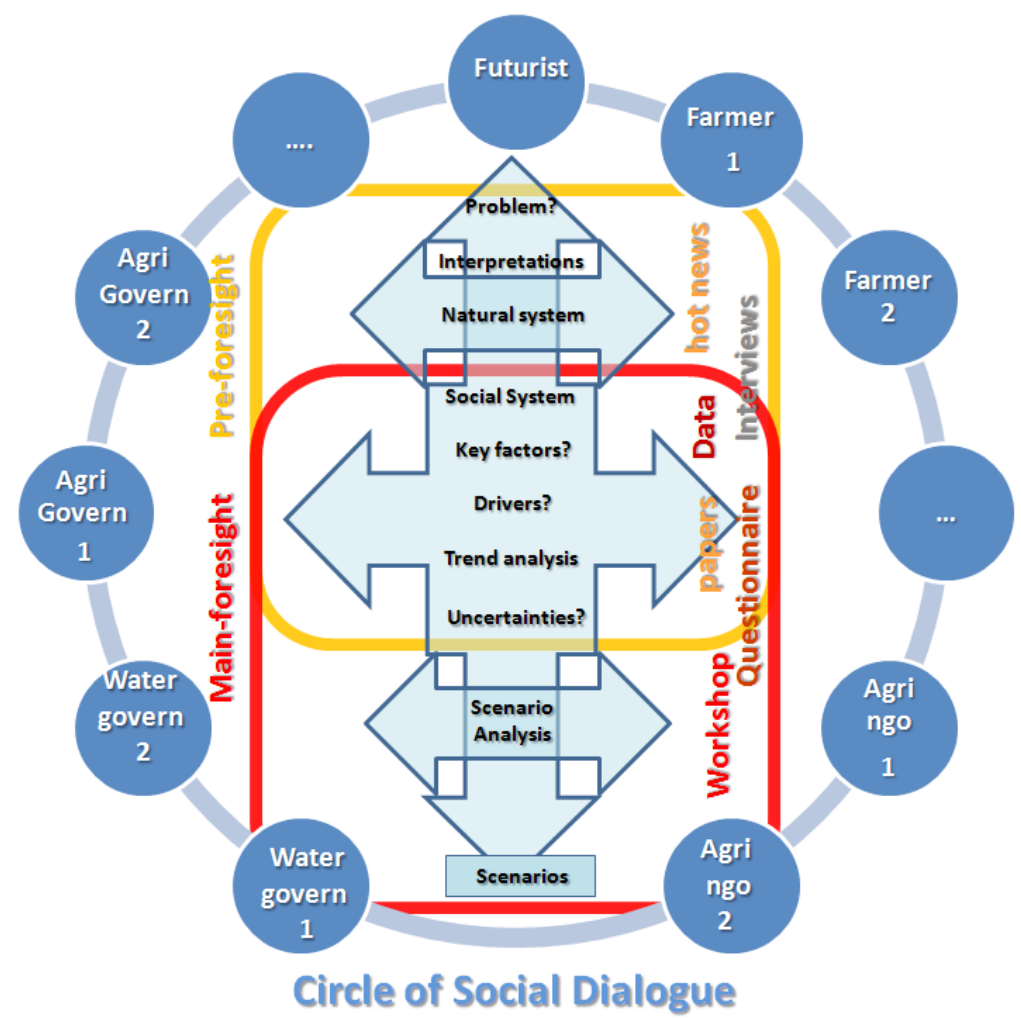

○ JSRD

Figure 5. Communication of stakeholders through the virtual workshop in the water supply and agricultural chains for exploring the scenarios (Resource: self-made)

nors, and policy-makers, registered in the virtual workshop; and special user names such as farmer 1, farmer 2, $\ldots$, agri-research 1 , agri-research $2, \ldots$, water-govern 1 , water-govern $2, \ldots$, etc., were assigned to them according to their professions and fields of experience. Then, each participant could make anonymous dialogues with others, and could change his/her opinions during the study. Therefore, the anonymity postulate of Delphi was applied. Also, this method can be regarded as a webbased Delphi method.

The researcher-made 34 structured interviews were conducted among the stakeholders and the results were uploaded onto the web-page. This method helped the stakeholders participate in structured dialogues, and they could easily revise their viewpoints about the challenges. During this phase, the futurist acted as a consultant and by presenting his judgment and viewpoints to the others and considering the problem from the standpoint of participants, encouraged them to discuss their interests and ideas.

\section{Findings}

Such structured dialogues had both properties of expert panel and Delphi method. The main difference of this Del- phi with the real-time Delphi could be the futurist role in their implementation. In virtual workshop, every stakeholder expressed his/her reasons about the future of crop irrigation systems in the process of virtual dialogues and futurist was present to organize the questions and responses of the participants. The 34 structured interviews were conducted among the stakeholders, and uploaded on the web-pages. This method helped the stakeholders to participate in structured dialogues and others could consider the information and they could easily revise their opinions about the water supply and agricultural water demand challenges. In this phase, the research problem and its importance were discussed, some scientific information and experiences about water supply and wheat production were exchanged and the essential interests of various stakeholders were brought up.

Consequently, to reduce the divergence between the understandings and interests of the main stakeholders, social dialogues and social learnings should be promoted to detect and solve social disparities. According to the IWRM and water governance literatures, and contents of interviews, participation of stakeholders was one of the main drivers with a high level of uncertainty ${ }^{3}$.

3. Some of the above findings, especially those related to the participation of stakeholders, were organized in the form of a ques- 
Also, the broad participation of stakeholders could be facilitated and their consensus and commitment could be promoted through a common vision. This research process requires the presence of a futurist to facilitate and implement structured dialogues. In this approach, the futurist may act as an participant-observant; however, through the methodology of positivism, he/she could only apply forecasting as an observer, but cannot participate in solving the disparities of opinions and interests among different stakeholder to build a desirable future. The results of the virtual workshop is categorized and given more detailed context in a real workshop to design the final scenarios. It seems that these structured dialogues could reduce the divergence in the understandings and interests of various stakeholders and increase their consensus and commitment.

Specific findings as specific results through the preforesight were: A- main differences opinion among stakeholders were: 1) Whether the amount of agricultural water withdrawal is $70 \%$ or $90 \%, 2$ ) Whether or not to build more dams in the future, 3) Which farm irrigation systems are more suitable to be used in the future based on the socioeconomic and environmental features, 4) Which crops, as wheat alternatives, are more suitable to be planted in the future based on the socioeconomic and environmental features, and 5) Whether it is necessary to become selfsufficient in wheat production. This concludes the major portion of the pre-foresight phase. 6) Results of a virtual

tionnaire and sent to participants for verification. session about priorities of 2 crop irrigation systems emphasized in national program 2025 is shown in Table 3.

Evaluating the efficacy of virtual workshop as a pre-foresight tool

During the pre-foresight futurist as a participant-observant facilitated and implemented structured dialogues among broad participation of stakeholders through the national side so it may promote their consensus and commitment through a common vision.

Pre-foresight phase was evaluated by 36 participants in a questionnaire survey. According to Table 4, the percentages of participants agreeing on the effectiveness of the examined issues (5Cs) were as follows: 1) Promoting thinking about the future $(91 \%), 2)$ Clarifying the effective factors $(88 \%), 3)$ Promoting systematic thinking $(91 \%), 4)$ Forming new networks and communications $(78 \%), 5)$ Promoting social learning about the study subject $(89 \%), 6)$ Promoting cooperation among the participants (72\%), and 7) Promoting consensus among the relevant stakeholders $(75 \%)$.

It seems that a virtual workshop is a useful method to achieve the general goals of IFS to study the futures of water supply for self-sufficient wheat production at national level. It can promote systematic thinking about the future through communication, social learning, and consensus among the main stakeholders. Therefore,

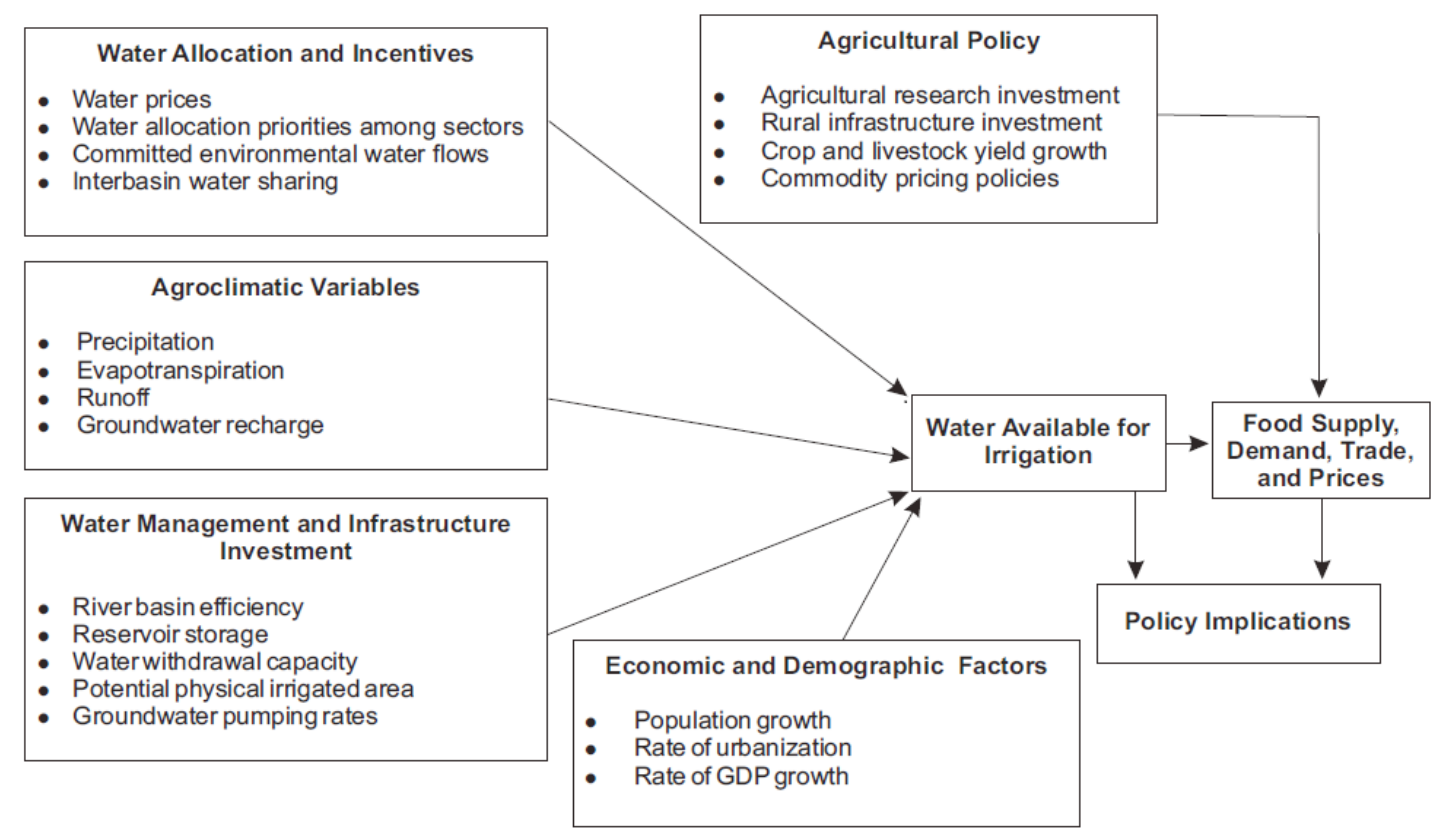

JSRD

Figure 6. Driving forces against water supply for food production at national level 
Table 3. Comparing two irrigation systems

\begin{tabular}{|c|c|c|}
\hline & Drip-Tape Irrigation System & Classic Irrigation System \\
\hline & Environmental damage due to use of plastic pipes & No environmental damage \\
\hline & Suitable for clay and sandy lands & Suitable for most lands \\
\hline \multirow[t]{3}{*}{$\begin{array}{l}\text { Ecological } \\
\text { features }\end{array}$} & Suitable for most waters & Suitable for low quality waters \\
\hline & Suitable for most land and even steep terrain & Suitable for flat lands \\
\hline & Reduce water evaporation & Increase water evaporation \\
\hline
\end{tabular}

JSRD

the current study achieved some of the IFS objectives, which could not have been achieved otherwise through the positivistic or critical paradigm by themselves.

\section{Discussion}

IWRM at water shield level and Water Good Governance are some global approaches for bringing stakeholders together to solve water challenges that look forward linearly to the future. AM is usually applied to solve water challenges through controllable uncertainties at watershed or national levels. It seems that coping water and food challenges at national level need new approaches in water supply and food production such as Integrated Water and Food Management (IWRFM). In other words, improving water supply for agricultural production at national level needs participation of different water use stakeholders from farm to watershed and national levels, through the national water managing process.
It needs improvement of the main stakeholder's relations via discourse and negotiations. Furthermore it needs a feedback mechanism and recognizing main uncertainties through the national water management (Table 5).

So clarifying the future is an essential task for managing IWRFM needs for suitable and acceptable FS paradigm and methodological process. Virtual workshop as a web based procedure according to IFS circumstances could prepare necessary background for implementing participatory scenario development in the main-foresight phase. Such structured dialogues have properties of both expert panel and Delphi method. This Delphi differs with the real-time Delphi in having the futurist role in their implementation. For example in virtual workshop all stakeholders express their reasons about the future of crop irrigation systems in the process of virtual dialogues and futurist organizes the questions and responses of the participants.

Table 4. Results of the survey on general research results

\begin{tabular}{|c|c|c|c|c|c|}
\hline \multirow{2}{*}{ Question } & \multicolumn{5}{|c|}{ Viewpoints of Participants on the Functionality of the Study } \\
\hline & Very Low & Low & Acceptable & High & Very High \\
\hline $\begin{array}{l}\text { How much the current study promoted thinking on the } \\
\text { future? }\end{array}$ & $2.8 \%$ & $2.8 \%$ & $44.4 \%$ & $30.6 \%$ & $16.7 \%$ \\
\hline $\begin{array}{l}\text { How much the current study clarified the discussed } \\
\text { effective factors? }\end{array}$ & - & $11.1 \%$ & $\% 50 \%$ & $22.2 \%$ & $16.7 \%$ \\
\hline $\begin{array}{c}\text { How much the current study promoted the systematic } \\
\text { thinking on the chain of water use and agriculture } \\
\text { production? }\end{array}$ & - & $8.3 \%$ & $38.9 \%$ & $41.7 \%$ & $11.1 \%$ \\
\hline $\begin{array}{l}\text { How much the current study promoted the communi- } \\
\text { cation among farmers, researchers, and policy-makers, } \\
\text { based on the subject of the study? }\end{array}$ & - & $22.2 \%$ & 22.2 & $41.7 \%$ & $13.9 \%$ \\
\hline $\begin{array}{l}\text { How much the current study promoted social learning, } \\
\text { based on the subject of the present study? }\end{array}$ & - & $11.1 \%$ & $22.2 \%$ & $38.9 \%$ & $27.8 \%$ \\
\hline $\begin{array}{l}\text { How much the current study promoted the consensus } \\
\text { among the stakeholders participated in the study? }\end{array}$ & - & $25 \%$ & $22.2 \%$ & $33.3 \%$ & $19.4 \%$ \\
\hline $\begin{array}{l}\text { How much the current study promoted the coopera- } \\
\text { tion among the stakeholders participated in the study? }\end{array}$ & $5.6 \%$ & $22.2 \%$ & $27.8 \%$ & $30.6 \%$ & $13.9 \%$ \\
\hline
\end{tabular}


Table 5. Comparing of water management approaches

\begin{tabular}{|c|c|c|c|c|}
\hline Approach & Looking futures & Scope & $\begin{array}{l}\text { Stakeholders partici- } \\
\text { pations }\end{array}$ & $\begin{array}{l}\text { Notice to agricul- } \\
\text { ture necessities }\end{array}$ \\
\hline IWRM & Linear-Weak & Reginal & Strong & Weak \\
\hline $\begin{array}{l}\text { Water Good } \\
\text { Governance }\end{array}$ & Linear-Weak & $\begin{array}{l}\text { Regional/ } \\
\text { National }\end{array}$ & Strong & Weak \\
\hline AM & $\begin{array}{l}\text { Multiple future- Controlable uncer- } \\
\text { tainty Relativly strong }\end{array}$ & $\begin{array}{l}\text { Regional/ } \\
\text { National }\end{array}$ & Strong & Relativly strong \\
\hline IWRFM & $\begin{array}{l}\text { Multiple future- Ucontrolable uncer- } \\
\text { tainty -Strong }\end{array}$ & $\begin{array}{l}\text { Regional/ } \\
\text { National }\end{array}$ & Strong & Strong \\
\hline
\end{tabular}

JSRD

Table 6. Comparing the Efficacies of Futures Studies Paradigms in Studying the Futures Contexts of Water Supply and Food Production

\begin{tabular}{|c|c|c|c|}
\hline Research Contexts & Positivistic FS & Critical FS & Integral FS \\
\hline $\begin{array}{l}\text { Paying attention to water resources and food production quantities and trends } \\
\text { at national level }\end{array}$ & + & - & + \\
\hline $\begin{array}{c}\text { Considering the natural and social factors as integrated and interrelated } \\
\text { systems }\end{array}$ & - & - & + \\
\hline Participation of different and scattered stakeholders at national level & - & - & + \\
\hline Considering the uncertainties related to social understanding & - & + & + \\
\hline $\begin{array}{l}\text { Progressive knowledge-building and management improvement through } \\
\text { learning-by-doing }\end{array}$ & - & - & + \\
\hline
\end{tabular}

It could promote systematic thinking about the future through communication, social learning, and consensus among the main stakeholders. Therefore this study has achieved some of the IFS objectives, which was otherwise impossible through the positivistic or critical paradigm. This research process requires the presence of a futurist for facilitating and implementing structured dialogues. In this approach, the futurist may act as an observant participant; however, through the methodology of positivism, he/she could only apply forecasting as an observer, but cannot participate in solving the disparities of opinions and interests among different stakeholder to build a desirable future. The results of the virtual workshop provided a more detailed context for designing and implementing main-foresight. As illustrated in Table 5 and Table 6, IFS seems to be more suitable paradigm for IWRMFP.

\section{Acknowledgements}

We appreciate the valuable and crucial help of the staff of Kanoon Eslami Ansar (http://kanoon-ansar.ir), as a proactive cultural NGO, for providing a friendly environment in which this study was conducted.

\section{Conflict of Interest}

The authors declared no conflict of interests.

\section{References}

Agricultural Engineering Research Institute. (2015). [Trends of Iran's agricultural production and the corresponding water use during the 2003-2012; Official letter of AERI to Ministry of Jehad Agriculture, Agricultural Engineering Research Institute (Persian)]. Karaj: Iran Agricultural Engineering Research Institute.

Aligica, P. D. (2003). Prediction, explanation and the epistemology of future studies. Futures, 35(10), 1027-1040. doi: 10.1016/ s0016-3287(03)00067-3

Allen, C. R., Fontaine, J. J., Pope, K. L., \& Garmestani, A. S. (2011). Adaptive management for a turbulent future. Journal of Environmental Management, 92(5), 1339-1345. doi: 10.1016/j. jenvman.2010.11.019

Agricultural Planning Economic and Rural Development Research Institute. (2016). [Agricultural planning economic and rural development research institute, increase of national production programs, food security and production of strategic products, Tehran, Iran (Persian)]. Retrieved from http://www.agri- 
peri.ir/File/ShowFile.aspx?ID=48c867b7-cf31-4f24-85aed39f51f9f134

Azimi, A. (2008). [Foresight Science and Technology (Experience of Republic of Czech) (Persian)]. Tadbir, 19(198)

Bell, W. (2011). Foundations of futures studies: Human science for a new era: Values, objectivity, and the good society. New Jersey: Transaction Publishers.

Brown, L. R. (2013). Food, fuel, and the global land grab. Futurist, $47(1), 21-26$.

Ehsani, M., \& Khaledi, H. (2003). [Understanding and improving agricultural water productivity for water and food security supply (Persian)]. Paper presented at The $11^{\text {th }}$ Conference of Iranian National Committee on Irrigation and Drainage, 24-25 December 2003.

Esmaeelifar, A .(2013). [Agriculture and food security, national security priority (Persian)]. Paper presented at $4^{\text {th }}$ International Economic Conference under Sanctions, Babolsar, Iran, 21 October 2016.

Food and Agriculture Organization. (2014). Municipal and industrial water withdrawal modelling for the years 2000 and 2005 using statistical methods [Internet]. Retrieved from http://www.fao.org/3/a-bc821e.pdf

Gáspár, T., \& Nováky, E. (2002). Dilemmas for renewal of futures methodology. Futures, 34(5), 365-379. doi: 10.1016/ s0016-3287(01)00065-9

Gavigan, J. P., James, P., Gavigan, L., Fabiana, S., Kenan, M., Miles, I., \& et al. (2001). Practical guide to regional foresight. Manchester: University of Manchester.

Georghiou, L. (1996). The UK technology foresight programme. Futures, 28(4), 359-377. doi: 10.1016/0016-3287(96)00013-4

Georghiou, L. (2003). Foresight: Concept and practice as a tool for decision making. Manchester: University of Manchester.

Gharib, H. (2011). [Food security in Iran vision (Persian)]. Rahbord, 21(65), 345-69.

Global Water Partnership. (2009). A handbook for integrated water resources management in basins, design and layout by scriptoria. Sweden: Elanders.

Haddeland, I., Heinke, J., Biemans, H., Eisner, S., Flörke, M., Hanasaki, N., \& et al. (2013). Global water resources affected by human interventions and climate change. Proceedings of the National Academy of Sciences, 111(9), 3251-3256. doi: 10.1073/ pnas. 1222475110

Hanjra, M. A., \& Qureshi, M. E. (2010). Global water crisis and future food security in an era of climate change. Food Policy, 35(5), 365-377. doi: 10.1016/j.foodpol.2010.05.006

Hassing, J., Ipsen, N., Jinch, C. T., Larsen, H., \& Lindgaard, J. P. (2006). Integrated water resources management in action. Denmark: Side Publications Series.

Hideg, É. (2013). Integral futures based on the paradigm approach. Futures, 45, 6-15. doi: 10.1016/j.futures.2012.11.007

Hideg, É., Nováky, E., \& Kristóf, T. (2013). Hungarian educational foresight: Vocational training and future. In K. Borch, S. Dingli, \& M. S. Jørgensen (Eds.), Participation and Interaction in Fore- sight Dialogue, Dissemination and Visions (pp. 223-37), USA Edward Elgar Publishing. doi: 10.4337/9781781956144.00019

Hideg, E., Nováky, E., \& Alács, P. (2014). Interactive foresight on the Hungarian SMEs. Foresight, 16(4), 344-359. doi: 10.1108/ fs-12-2012-0091

Hooper, B. P. (2011). Integrated water resources management and river basin governance. Journal of Contemporary Water Research and Education, 126(1), 3.

Huitema, D., Mostert, E., Egas, W., Moellenkamp, S., Pahl-Wostl, C., \& Yalcin, R. (2009). Adaptive water governance: Assessing the institutional prescriptions of adaptive management from a governance perspective and defining a research agenda. Ecology and Society, 14(1). doi: 10.5751/es-02827-140126

Javan, J., FalSoleyman, M. (2008). [Water crisis and need for attention to productivity of agricultural water in arid regions, Case Study: Birjand plain (Persian)]. Geography and Development, 6(11), 115-138.

Julsrud, T. E., \& Priya Uteng, T. (2015). Technopolis, shared resources or controlled mobility? A net-based Delphi-study to explore visions of future urban daily mobility in Norway. European Journal of Futures Research, 3(1). doi: 10.1007/s40309 015-0069-6

Keshavarz, A., Sadeghzadeh, K. (2000). [Management of water use in agriculture, estimation of future demand, current status, future prospects and solutions to optimise water use (Persian)]. Tehran: Agriculture Research, Education and Promotion Institute.

Khadem Adam, N. (2000). [Food security in national strategy (Persian)]. Tamin Ejtemaie, 1(2), 3-4.

Mahajan, V., Linstone, H. A., \& Turoff, M. (1976). The Delphi mmethod: Techniques and applications. Journal of Marketing Research, 13(3), 317. doi: 10.2307/3150755

Mettler, P. H. (2005). Epistemology of futures research in "Blickpunkt Zukunft". Retrived from http:/ / www.peter-h-mettler. $\mathrm{eu} / \mathrm{engl} /$ contact.html

Mircholi, F., Faramarzi, M., \& Soltani, S. (2013) [Impact of virtual water to ecosystem (Persian)]. Paper presented at The First International Conference of IALE, Iran, Isfahan, 30-31 October 2013

Mohajeri, S., Horlemann, L., Sklorz, S., Kaltofen, M., Ghanavizchian, S., \& Nuñez von Voigt, T. (2016). Integrated water resource management in Isfahan: The Zayandeh Rud catchment. Concept. Research and Implementation, 603-627. doi: 10.1007/978-3-319-25071-7_23

Morgan, D. (2011). Futures and the Future: An integral response to epistemological pluralism in futures studies. Journal of Integral Theory and Practice, 6(2), 112-134.

Nikuee A, Zibaee M. (2012). [Water resource management and food security in Zayande Rud basin: Application of integrated analysis of river basin (Persian)]. Agriculture Economics and Development Agricultural Science and Technology, 26(3), 183-196.

Nozari, H., \& Kiumarsi, F. (2015). [Agricultural water resources management according virtual water approach (Persian)]. Paper presented at National Conference of Water Crisis in Iran and Middle East, Iran, Shiraz, 11 March 2015. 
Organisation for Economic Co-operation and Development (2015). Principles on Water Governance. Paper presented at Ministerial Council Meeting. Paris, France, 4 June 2015.

Pahl-Wostl, C., Sendzimir, J., Jeffrey, P., Aerts, J., Berkamp, G., \& Cross, K. (2007). Managing change toward adaptive water management through social learning. Ecology and Society, 12(2). doi: 10.5751/es-02147-120230

Paydar Golsang, A. (2013). [Optimal policy model of groundwater resource utilization for agricultural activities in rural areas - geographical and cultural basin of Halil Rud, Jiroft plain (Persian)] (PhD thesis). Tehran: Terbia Modarres University.

Renault, D. (2003). Value of virtual water in food: Principles and virtues. Rome: Food and Agriculture Organization of the United Nations.

Revenga, C. (2006). World water and food to 2025: Dealing with scarcity. Economica, 73(292), 789-791. doi: 10.1111/j.14680335.2006.00039_3.x

Safavi, H. R., \& Shisheforoosh, M. (2013). [Necessity for integrated water resources management for confrontation with water crisis (Persian)]. Paper presented at First National Conference on Water Crisis, Isfahan, Iran, 15-16 May 2013.

Steduto, P., Faurès, J. M., Hoogeveen, J., Winpenny, J., \& Burke, J. (2012). Coping with water scarcity: An action framework for agriculture and food security. Rome: Food and Agriculture Organization of the United Nations Rome.

Slaughter, R. A. (1999). A new framework for environmental scanning. Foresight, 1(5), 441-451. doi: 10.1108/146366899910802331

Teruhisa, T., \& Yoshika, Y. (2006). Technology foresight survey in china. Quarterly Review, 20, 101-112.

United Nations Industrial Development Organization. (2005). United nations industrial development organization technology foresight mmanual, Volume 1: Organization and Methods [Internet]. Rerived from http://www.research.gov.ro/img/files up/1226911327TechFor_1_unido.pdf

United States Department of Agriculture, Foreign Agricultural Service. (2008). Iran: 2008/09 Wheat Production Declines Due to Drought SheikhAli [Internet]. Rerived from https://www. pecad.fas.usda.gov/highlights/2008/05/Iran_may2008. htm\#top

United Nation. (2014). UN water. Retrived from http://www. unwater.org/downloads/water_for_food.pdf.

Van Vught, F. A. (1987). Pitfalls of forecasting. Futures, 19(2), 184-196. doi: 10.1016/0016-3287(87)90050-4

Voros, J. (2003). A generic foresight process framework. Foresight, 5(3), 10-21. doi: 10.1108/14636680310698379

Zareie, Gh., Jafari, M. A. (2011). [The role of import and export of major crop productions in virtual water trade and water footprint in agricultural sector of Iran (Persian)]. Iranian Journal of Irrigation and Drainage, 9(5), 784-97.

Zargarpur, R., Nourzad, R. (2009). [A conceptual model of integrated water resources management for national water security (Persian)]. Iran Water Resources Research, 5(3), 1-3. 
